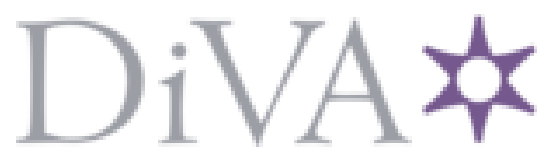

http://www.diva-portal.org

This is the published version of a paper published in European Journal of Glass Science and Technology. Part A: Glass Technology.

Citation for the original published paper (version of record):

Karlsson, S., Sharafat, A., Limbach, R., Strand, M., Wondraczek, L. (2015)

Alkali salt vapour deposition and in-line ion exchange on flat glass surfaces

European Journal of Glass Science and Technology. Part A: Glass Technology, 56(6):

203-213

https://doi.org/10.13036/1753-3546.56.6.203

Access to the published version may require subscription.

N.B. When citing this work, cite the original published paper.

Permanent link to this version:

http://urn.kb.se/resolve?urn=urn:nbn:se:ri:diva-28014 


\title{
Alkali salt vapour deposition and in-line ion exchange on flat glass surfaces
}

\author{
Stefan Karlsson, ${ }^{1,2 *}$ Sharafat Ali, ${ }^{3}$ René Limbach, ${ }^{2}$ Michael Strand ${ }^{3}$ E Lothar Wondraczek ${ }^{2}$ \\ ${ }^{1}$ Glafo - the Glass Research Institute, PG Vejdes väg 15, SE-351 96 Växjö, Sweden \\ ${ }^{2}$ Otto Schott Institute of Materials Research, Friedrich Schiller University of Jena \\ Fraunhoferstraße 6, D-07743 Jena, Germany \\ ${ }^{3}$ Faculty of Technology, Linnæus University SE-351 95 Växjö, Sweden
}

Manuscript received 16 January 2015

Revision received 20 May 2015

Manuscript accepted 10 June 2015

This study suggests a different route for the modification of flat/float glass surfaces; i.e. exchange of ionic species originating from in-line vapour deposition of salt as compared to the conventional route of immersing the glass in a molten salt bath. The aim of this work is to develop a more flexible and, eventually, more rapid process for improving the mechanical strength of flat glass by introducing external material into the surface. We discuss how chemical strengthening can be performed through the application of potassium chloride on the glass surface by vapour deposition, and in-line thermally activated ion exchange. The method presented here has the potential to be up-scaled and to be used in in-line production in the future, which would make it possible to produce large quantities of chemically strengthened flat glass at a considerably lower cost.

\section{Introduction}

Glassy materials provide a unique set of properties, such as transparency, high hardness and good chemical durability, forming ability, low cost production and the possibility of recycling. They are therefore used in a wide range of applications, e.g. windows, containers, displays, thermal insulation, optical lenses, data transport, or, e.g. as bioactive materials. The fact that glass is a relatively hard material originates from the nature and the alignment of bonds of the vitreous network. The mechanical strength, on the other hand, mainly depends on the presence of defects in the glass surface, see Figure 1, and, hence,

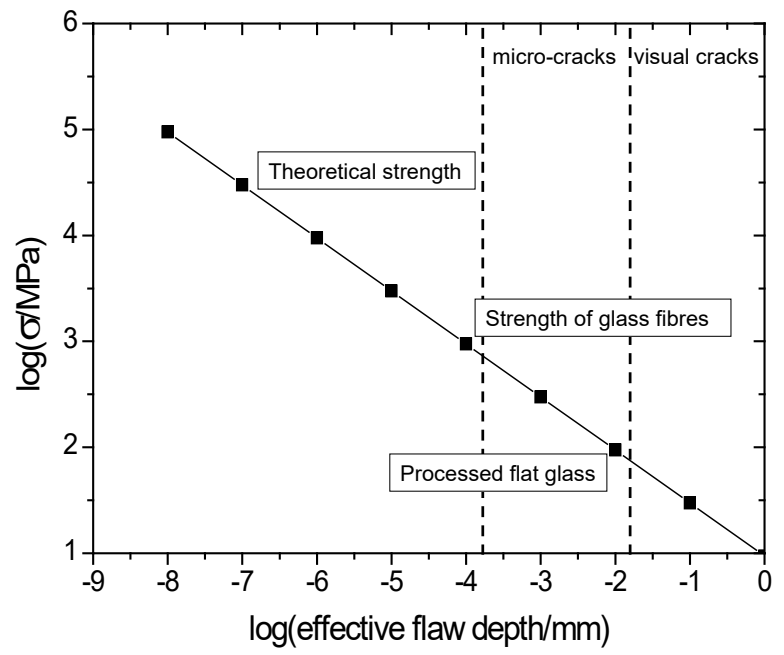

Figure 1. The effect of surface flaws on the tensile strength of soda-lime-silica glass $^{(4)}$

${ }^{1}$ Corresponding author. Email stefan.karlsson@glasfo.se DOI: 10.13036/1753-3546.56.6.203 the defect resistance of this surface. ${ }^{(1-3)}$ As a consequence, the practical use of glass is often limited by its brittleness, which is associated with statistical failure.

There exist a variety of ways to increase the strength of glass, ${ }^{(1)}$ most of them involve modifications of the glass surface..$^{(5)}$ A method, which has received much attention, is chemical strengthening. It is based on the exchange of smaller ions in the glassy matrix by larger ions from a molten salt, e.g. $\mathrm{Na}^{+}$is replaced by $\mathrm{K}^{+}$, see Figure 2 . The larger ions are literally squeezed into the sites of the smaller ions, generating compressive stresses in the glass surface, which counteract external tensile stresses.

The most commonly described route of chemical strengthening is $\mathrm{K}^{+}-\left(\mathrm{Li}^{+}, \mathrm{Na}^{+}\right)$ion exchange, which was discovered independently by Kistler ${ }^{(6)}$ and Acloque. ${ }^{(7)}$ Chemical strengthening of glass has recently been

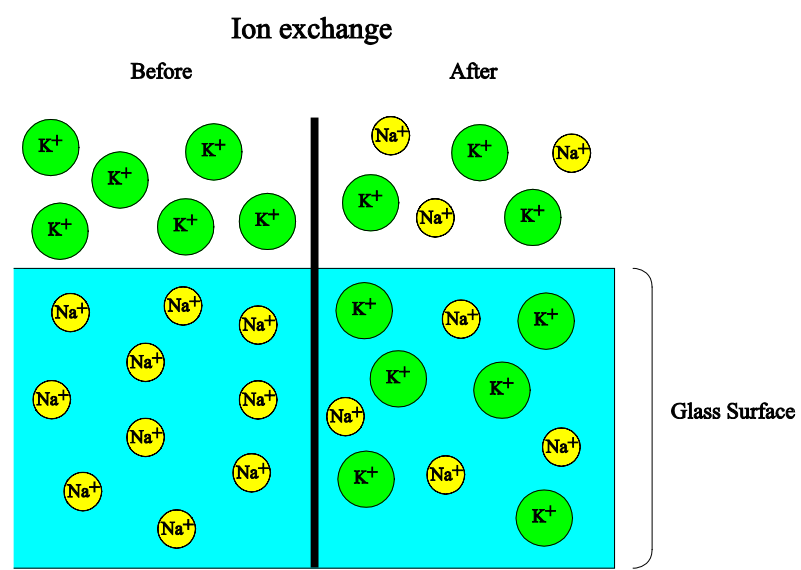

Figure 2. Schematic ion exchange process for the modification of glass surfaces [Colour available online] 


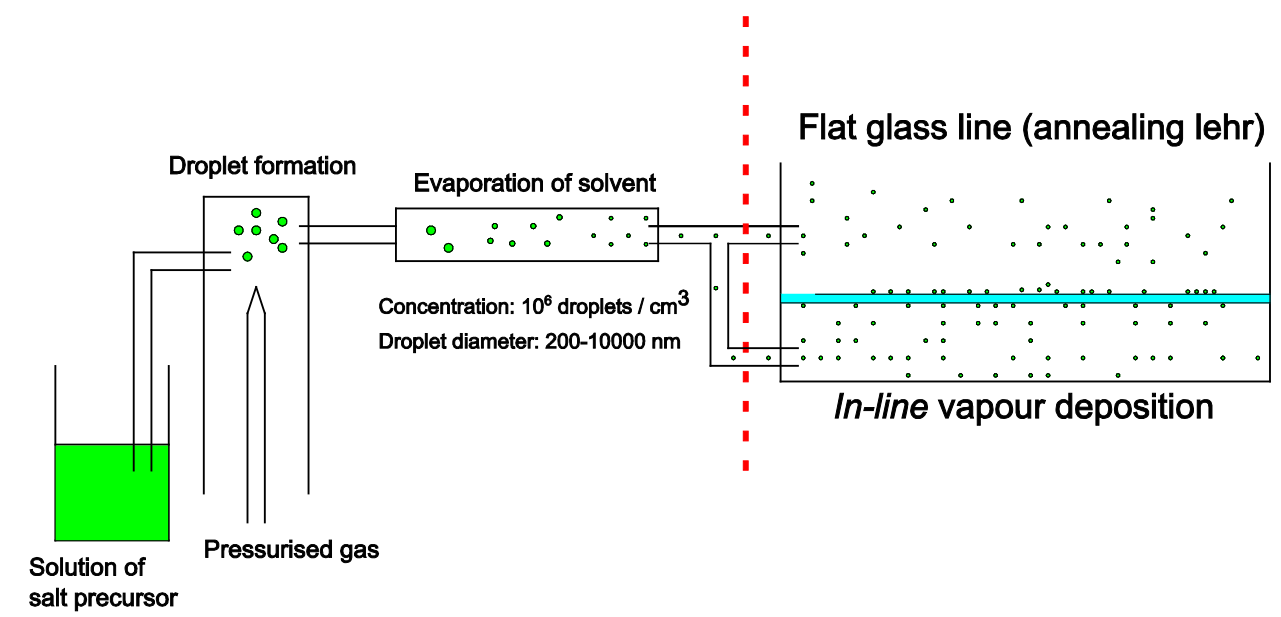

Figure 3. Schematic illustration of the in-line vapour deposition of salt for chemical strengthening of flat glass [Colour available online]

reviewed by several authors. ${ }^{(5,8-11)}$ Although this method was introduced more than half a century ago, it has failed to be widely adopted in the market for a long time. However, in recent years, large specialty glass companies launched chemically strengthened flat glass, e.g. Corning Gorilla Glass, ${ }^{(12)}$ Schott Xensation, ${ }^{(13)}$ AGC Dragontrail ${ }^{(14)}$ and NEG CX-01. ${ }^{(15)}$ Nowadays, most touchscreens in commercially available smartphones are made of chemically strengthened flat glass ${ }^{(16)}$ regardless of the considerably higher cost which is associated with the production process of such glass. However, for other applications, where larger glass sheets are required, such as covers for photovoltaic cells, car windows, facades or furniture, the production cost of chemically strengthened glass is still too high. Recently, alternative approaches have been presented, where the glass is spray-coated with a salt mixture and subsequently dried as well as heat treated. ${ }^{(17)}$

Chemical strengthening of glass is complex and many parameters affect the ion exchange process as well as the resulting strength: ${ }^{(18)}$

i. The effect of temperature on the interdiffusion coefficient,

ii. The time of exchange,

iii. The interfacial energy between the glass and the salt

iv. The phase boundary reaction barrier and adsorption enthalpy at the glass surface,

v. The glass composition,

vi. The exchanging pair of ions,

vii. The influence of temperature on relaxation.

With the present knowledge, many of these parameters have been optimised for specific products. There is, however, another possibility for a further cost reduction in the fabrication of chemically strengthened glass namely by optimising the large-scale process. Optimisation of industrial processes is most often performed by an automation of the process. ${ }^{(19)}$

In principal, chemically strengthened flat glass is manufactured by immersing a flat glass sheet into a molten salt bath. However, there are also other methods for chemical strengthening such as salt-spray as has been both studied ${ }^{(20)}$ and commercialised, in the former GDR ${ }^{(21,22)}$ and recently. ${ }^{(23)}$ In this study we suggest vapour deposition and in-line alkali metal ion exchange, see Figure 3. This method is based on an earlier study by Sil'vestrovich et al. ${ }^{(24,25)}$ However, in contrast to the approach of Sil'vestrovich et al, where the vapour deposition and the ion exchange process were separated into two different steps, we combine both processes into one step, which enables a novel route for the fabrication of low-cost chemically strengthened glass.

\section{Experimental Procedure}

The glass used here was a conventional soda-limesilica float glass provided by Pilkington Floatglas AB, with a nominal thickness of $4 \mathrm{~mm}$, denoted as 'Ref' in this paper. The chemical composition was analysed using different wet chemical methods, e.g. atomic absorption spectroscopy (AAS). The dissolution of the sample and quantification followed BS 2649, ${ }^{(26)}$ except for $\mathrm{TiO}_{2}$ and $\mathrm{SO}_{3}$. Due to safety reasons nitric acid and hydrochloric acid replaced perchloric acid. The normalised chemical composition of the float glass used in the experiments is given in Table 1.

Table 1. Normalised chemical composition of the float glass used in the experiments

\begin{tabular}{lrr} 
& wt $\%$ & mol\% \\
\hline $\mathrm{SiO}_{2}$ & $72 \cdot 80$ & $71 \cdot 32$ \\
$\mathrm{Na}_{2} \mathrm{O}$ & $13 \cdot 39$ & $12 \cdot 72$ \\
$\mathrm{~K}_{2} \mathrm{O}$ & $0 \cdot 04$ & $0 \cdot 03$ \\
$\mathrm{Al}_{2} \mathrm{O}_{3}$ & $0 \cdot 12$ & $0 \cdot 07$ \\
$\mathrm{MgO}$ & $4 \cdot 07$ & $5 \cdot 94$ \\
$\mathrm{CaO}$ & $9 \cdot 25$ & $9 \cdot 71$ \\
$\mathrm{Fe}_{2} \mathrm{O}_{3}$ & $0 \cdot 10$ & $0 \cdot 04$ \\
$\mathrm{SO}_{3}$ & $0 \cdot 21$ & $0 \cdot 16$ \\
$\mathrm{TiO}_{2}$ & $0 \cdot 02$ & $0 \cdot 01$ \\
$\mathrm{Sum}$ & 100 & 100
\end{tabular}




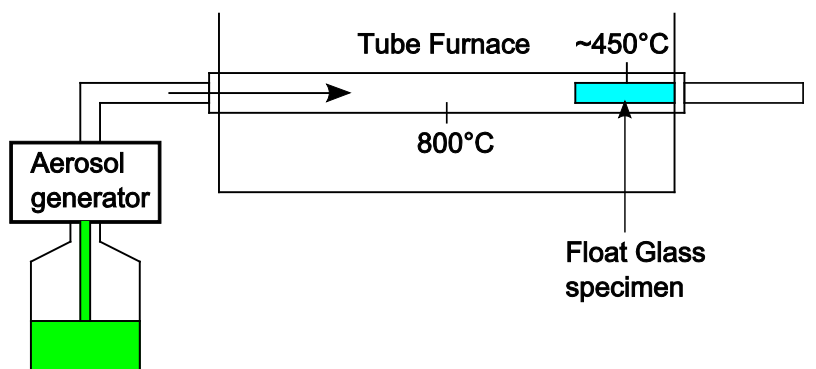

Figure 4. Schematic illustration of the experimental setup of the vapour deposition and in-line ion exchange [Colour available online]

The experimental setup is given in Figure 4. An aerosol generator from PALAS Particle Technology model AGK 2000 was used. It was consistently run at 2 bar pressurised air in the experiments. The tube furnace was a Carbolite Tube Furnace model $12 / 65 / 550$ with a maximum temperature of $1200^{\circ} \mathrm{C}$. The temperature distribution was measured with thermocouples - in the centre of the furnace it was $800^{\circ} \mathrm{C}$ (initially $700^{\circ} \mathrm{C}$ ), while the specimen was placed at the cold end of the furnace where the temperature was around $450^{\circ} \mathrm{C}$. For the ion exchange, the glass specimens were cut into pieces of $2 \times 10 \mathrm{~cm}$, cleaned with ethanol and distilled water, and subsequently dried for weighing. Reagent grade quality $\mathrm{KCl}$ delivered by Scharlau Chemie SL was mixed with distilled water to obtain solutions of 10,15 and $20 \mathrm{~g}$ salt, respectively, per $100 \mathrm{ml} \mathrm{H}_{2} \mathrm{O}$. The ion exchange was performed for 2, 4 and $6 \mathrm{~h}$, respectively, at a temperature of $450 \pm 60^{\circ} \mathrm{C}$.

\section{Characterisation}

The thickness of the deposited salt layer was analysed using an optical profilometer, NPFLEX 3D Surface Metrology System from Bruker Corporation, equipped with an objective with $\times 5$ magnification. The salt layer was removed in the centre of the sample to create a groove, which enabled estimation of the thickness of the deposited salt layer, see Figure 5.

A scanning electron microscope (SEM) equipped with an energy dispersive spectrometer (EDS) was used for analysing concentration depth profiles of the specimens. The SEM was a JEOL JXA 840A and the EDS, Oxford Instruments 6506. The SEM/EDS instrument was calibrated using a cobalt standard. The samples were embedded in an epoxy resin and coated with carbon. Concentration depth profiles were obtained, by performing line scans along a cross section in the centre of the specimens, where the treatment temperature was approximately $450^{\circ} \mathrm{C}$, see Figure 4 . The count time was set to $30 \mathrm{~s}$ at $60 \mu \mathrm{A}$ and $20 \mathrm{kV}$. The displayed concentration profiles in section 3.2 are given as the average of line scans at three different locations. Based on these results, the effective diffusion coefficients $\bar{D}$ were calculated, according to Green's function, ${ }^{(27)}$ where $\mathrm{C}$ is the concentration, $x$ the depth and $t$ the time:

$C=\frac{A}{\sqrt{t}} \exp \left(\frac{-x^{2}}{4 \bar{D} t}\right)$

Reflectance, $R \%$, was determined with an Agilent Technologies UV-VIS-NIR spectrometer; model Cary 5000, equipped with an integration sphere. The reflectance was measured at the hot-end of the glass samples in a range of $200-2500 \mathrm{~nm}$ and with scan rate of $10 \mathrm{~nm} / \mathrm{s}$. The refractive index was calculated from the reflectance spectra using to Equation (2), where $n_{\mathrm{s}}$ is the refractive index of the glass at $520 \mathrm{~nm}$. It should be noted that other equations can be used to calculate the refractive index from the reflectance spectra; as consequence, the current results are comparable to each other, but not to other published results.

$n_{\mathrm{s}}=\frac{1+R+\sqrt{R}}{1-R}$

Infrared reflectance spectra (IR-RS) were measured with a Shimadzu Scientific Instruments spectrometer, model IRAffinity-1. The reflectance spectra were recorded over the range $400-4000 \mathrm{~cm}^{-1}$, with a resolution of $4 \mathrm{~cm}^{-1}$. All spectra were averaged over 64 scans and transformed according to the Kramers-Kronig transformation. Aluminium mirror was used was used as a baseline. The IR-RS spectra were measured at the hot end of the glass samples.

Mechanical properties were determined with an Agilent Technologies G200 nanoindenter, equipped with a three-sided Berkovich diamond tip. On each specimen 10 indents up to $2 \mu \mathrm{m}$ deep were made at a constraint strain-rate of $0.05 \mathrm{~s}^{-1}$. The hardness $\mathrm{H}$ and elastic modulus $\mathrm{E}$ were recorded as a function of the displacement $h$ and the resulting values were averaged over $400-1800 \mathrm{~nm}$ depth. For a detailed description of the method we refer to Limbach et al. ${ }^{(28)}$ The indentation measurements were performed at the cold end of the glass specimen.

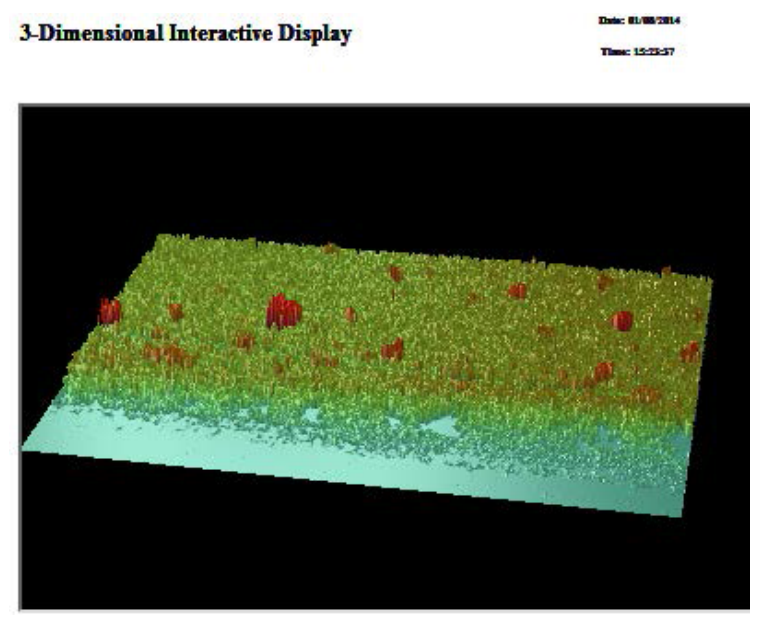

Figure 5. Optical profilometer 3D vision of the groove created in the salt layer [Colour available online] 


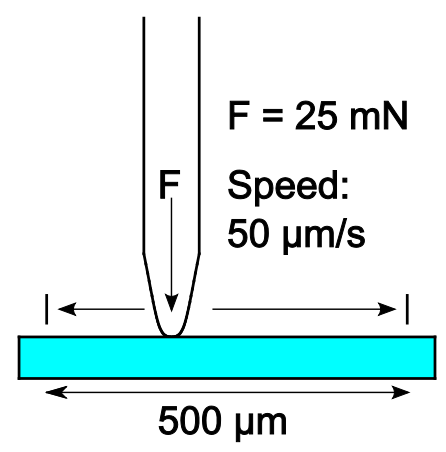

Figure 6. Schematic illustration of the scratch/wear resistance test [Colour available online]

The scratch/wear resistance was measured with the nanoindenter described above, equipped with a conical diamond tip, with a half-included angle of $60^{\circ}$ and a nominal tip radius of $5 \mu \mathrm{m}$. In total, 100 wear cycles with a constant load of $25 \mathrm{mN}$ were made over a length of $500 \mu \mathrm{m}$, at constant speed of $50 \mu \mathrm{m} / \mathrm{s}$. A schematic illustration of the scratch/wear resistance tests are shown in Figure 6. All results were averaged over five different measurements. The scratch/wear resistance was measured at the cold end of the glass samples.

\section{Results and discussion}

The weights of the deposited $\mathrm{KCl}$ salt as well as the thickness of the layers obtained by the vapour deposition are summarized in Table 2. In Figure 7 the deposit of the $\mathrm{KCl}$ salt on the glass samples has been plotted against the thickness of the corresponding layer. Fairly linear trends can be seen for the different concentrations, which proves the applicability of the salt deposition with the current experimental setup. Similar trends were also observed for the relationship between the treatment time and the thickness of the deposited layer. On the other hand, the deposit of salt and the thickness of the deposited layer show an exponential relationship with the $\mathrm{KCl}$ concentration.

\subsection{Concentration profiles}

The deposited salt reacts with the glass surface via an ion exchange process that can be described by Equa-

Table 2. Deposit results expressed as weight of change with salt and thickness of salt layer

\begin{tabular}{llll}
$\begin{array}{l}\mathrm{KCl} \text { Conc. } \\
\left(\mathrm{g} / 100 \mathrm{ml} \mathrm{H} \mathrm{H}_{2}\right)\end{array}$ & Time $(h)$ & $\begin{array}{l}\text { Deposit of salt } \\
\text { on sample }(\mathrm{g})\end{array}$ & $\begin{array}{l}\text { Thickness of } \\
\text { salt layer }(\mu \mathrm{m})\end{array}$ \\
\hline 10 & 2 & $0 \cdot 0028$ & $1-4$ \\
15 & 2 & $0 \cdot 0031$ & $1-4$ \\
20 & 2 & $0 \cdot 0037$ & $4-16$ \\
10 & 4 & $0 \cdot 0054$ & $2-14$ \\
15 & 4 & $0 \cdot 0086$ & $2-20$ \\
20 & 4 & $0 \cdot 0287$ & $30-45$ \\
10 & 6 & $0 \cdot 0107$ & $25-35$ \\
15 & 6 & $0 \cdot 0170$ & $30-40$ \\
20 & 6 & $0 \cdot 0330$ & $50-60$
\end{tabular}

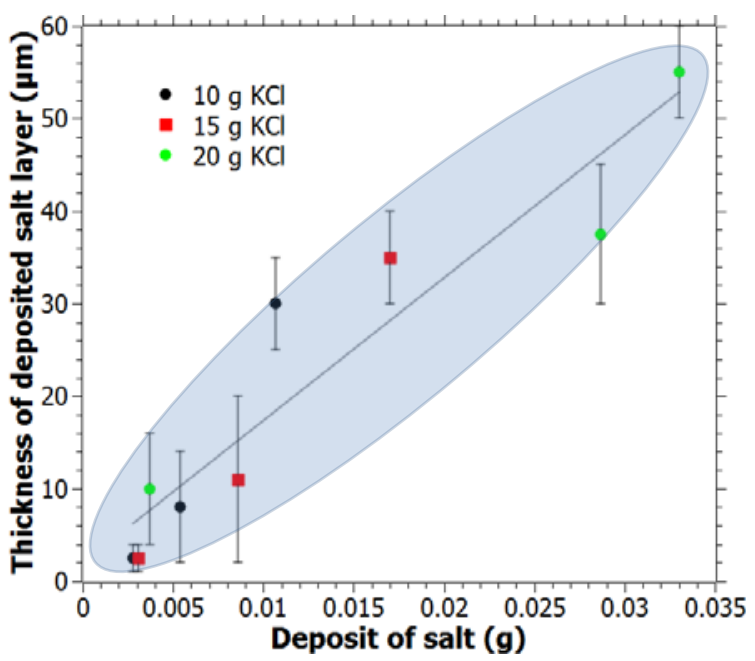

Figure 7. Thickness of deposited salt layer in $\mu \mathrm{m}$ as a function of deposit of salt in grams, the line is a linear fit of all data and the ellipse is a guide to the eye for the experimental accuracy [Colour available online]

tion (3). Ion exchange is driven by thermodynamics of the reaction, i.e. a gradient in the chemical potential or the Gibb's free enthalpy. ${ }^{(29)}$ In the present case the concentration gradient between the salt and the glass surface can be considered as the driving force for the ion exchange. The deposited salt contains $\mathrm{K}^{+}$ions which substitutes the $\mathrm{Na}^{+}$ions in the glass surface.

$\overline{\mathrm{A}}_{\text {glass }}+\mathrm{B}_{\text {salt }} \rightleftharpoons \overline{\mathrm{B}}_{\text {glass }}+\mathrm{A}_{\text {salt }}$

The effectiveness of the ion exchange can be estimated by the effective diffusion coefficient, which can be determined from the concentration profiles. In Figure 8(a)-(c) the average concentration profiles are shown for an ion exchange with concentrations of 10,15 and $20 \mathrm{~g} \mathrm{KCl}$, respectively, per $100 \mathrm{ml} \mathrm{H}_{2} \mathrm{O}$ and treatment times of 2,4 and $6 \mathrm{~h}$, respectively. The results indicate that both the treatment time and the concentration matter, with the former having the larger impact. In general, after $2 \mathrm{~h}$ of treatment the

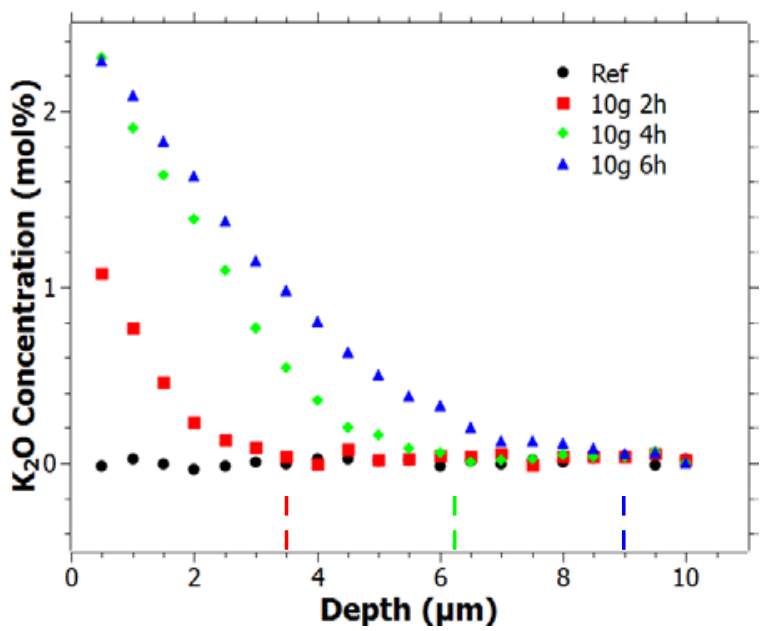

Figure 8(a). Average concentration profiles of float glasses treated with $10 \mathrm{~g} \mathrm{KCl} \mathrm{per} 100 \mathrm{ml} \mathrm{H} \mathrm{H}_{2} \mathrm{O}$ [Colour available online] 


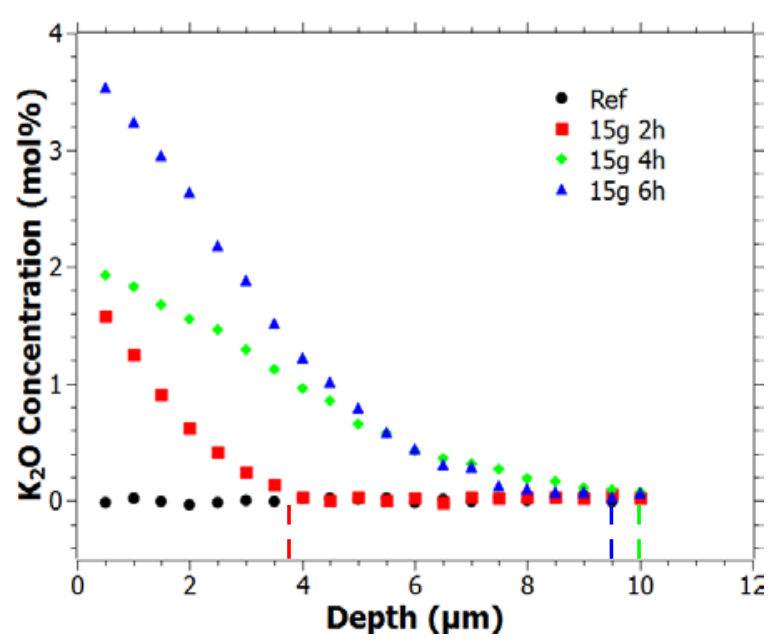

Figure 8(b). Average concentration profiles of float glasses treated with $15 \mathrm{~g} \mathrm{KCl}$ per $100 \mathrm{ml} \mathrm{H}_{2} \mathrm{O}$ [Colour available online]

$\mathrm{K}_{2} \mathrm{O}$ concentration diminishes at around $4 \mu \mathrm{m}$, while in the samples treated for 4 and $6 \mathrm{~h}$ the $\mathrm{K}^{+}$penetration exceeds depths of $6 \mu \mathrm{m}$. The penetration depth for each treatment is marked with dashed lines in Figures $8(\mathrm{a})-(\mathrm{c})$. It has to be noted, that the $4 \mathrm{~h}$ treatment with a concentration of $15 \mathrm{~g} \mathrm{KCl}$ per $100 \mathrm{ml} \mathrm{H}_{2} \mathrm{O}$ gave a somewhat different profile compared to the remaining ones. This might be due to a discrepancy in the experiment, which cannot be explained so far. In general, the results indicate that a salt concentration of $10<x<20 \mathrm{~g} \mathrm{KCl}$ per $100 \mathrm{ml} \mathrm{H}_{2} \mathrm{O}$ and treatment times between $2-6 \mathrm{~h}$ promote the kinetics of the ion exchange process. In the study of Sil'vestrovich et $a l^{(24)}$ somewhat larger penetration depths for the $\mathrm{K}^{+}$ ions were obtained. However, this difference can be explained by the variations in the experimental setup, i.e. the two step procedure used by Sil'vestrovich et al compared to the one step procedure in the current work. As can be seen by Figure 8(d), the natural log-

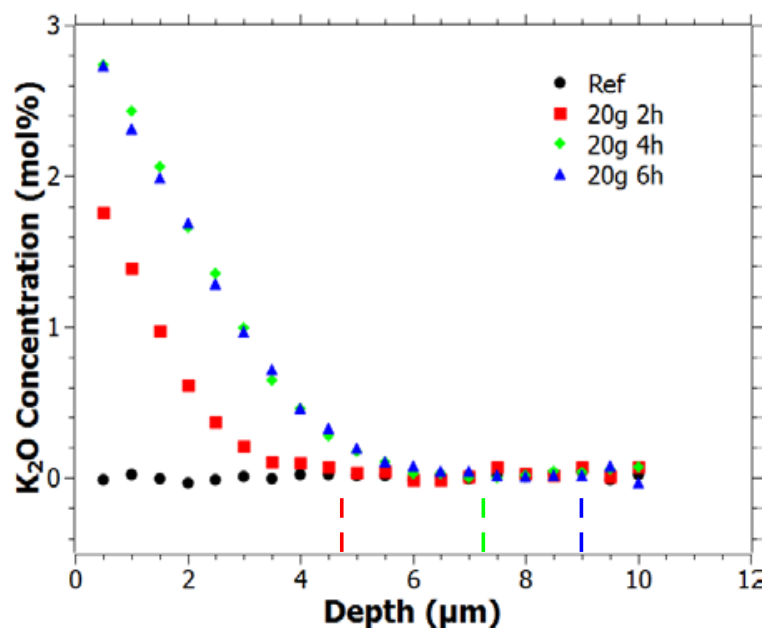

Figure 8(c). Average concentration profiles of float glasses treated with $20 \mathrm{~g} \mathrm{KCl}$ per $100 \mathrm{ml} \mathrm{H} \mathrm{H}_{2} \mathrm{O}$ [Colour available online]

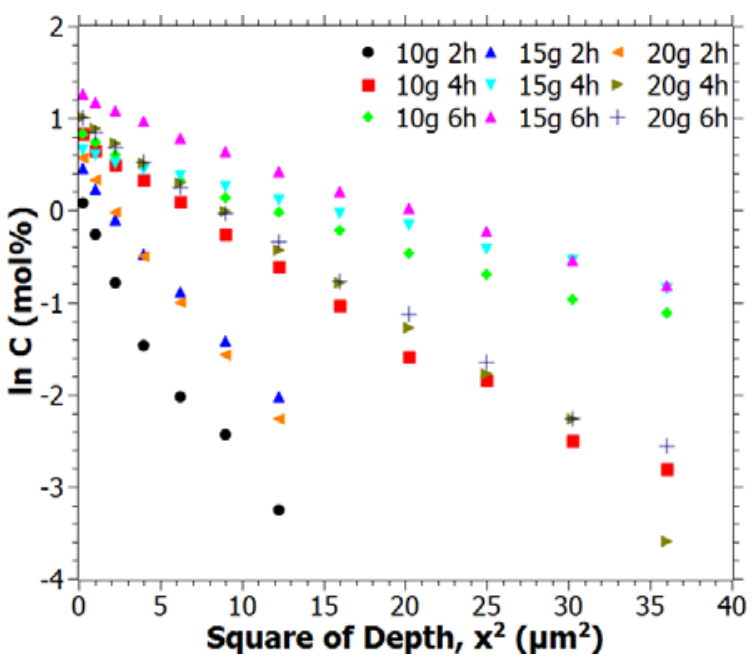

Figure $8(d)$. Natural logarithm of the $\mathrm{K}_{2} \mathrm{O}$ concentration as function of the square of depth [Colour available online]

arithm of the $\mathrm{K}_{2} \mathrm{O}$ concentration in the glass surface follows the function of the square of depth, which indicates that it is a diffusion driven process.

\subsection{Effective diffusion coefficients}

The effective diffusion coefficients were calculated from the concentration profiles according to Green's function (c.f. Equation (1)). In the calculations the concentration values of $\mathrm{K}_{2} \mathrm{O}$ between $0.5-3 \cdot 5 \mu \mathrm{m}$ were used for the glass specimens treated for $2 \mathrm{~h}$, while the values between $0 \cdot 5-6 \cdot 0 \mu \mathrm{m}$ were used for the glass specimen treated for 4 and $6 \mathrm{~h}$, respectively (c.f. Figures 8(a)-(c)). The calculated effective diffusion coefficients are given in Table 3 . It can be seen that the values of ranges between $1 \cdot 2 \times 10^{-12}$ and $4 \cdot 2 \times 10^{-12}$. These values are considerably lower than previously reported ones. ${ }^{(27)}$ However, there are many parameters that affect the ion exchange kinetics. An important factor is assumed to be the thickness of the deposited salt layer, which is very thin. In a thinner salt layer the concentration of $\mathrm{K}^{+}$ions will decrease more rapidly as the ion exchange process proceeds and despite the short treatment times it might even be depleted. This might be the reason why the optimal treatment time for the current study is indicated to be less than $6 \mathrm{~h}$.

Table 3. Effective diffusion coefficients calculated with Green's function from the averaged $\mathrm{K}_{2} \mathrm{O}$ concentration profiles (c.f. Figures 8(a)-(c))

\begin{tabular}{lll}
$\begin{array}{l}\mathrm{KCl} \text { concentration } \\
(\mathrm{g} / 100 \mathrm{ml} \mathrm{H} \mathrm{O})\end{array}$ & $\begin{array}{l}\text { Treatment time } \\
(\mathrm{h})\end{array}$ & $\begin{array}{l}\text { Effective diffusion } \\
\text { coefficient }\left(\mathrm{cm}^{2} \mathrm{~s}^{-1}\right)\end{array}$ \\
\hline 10 & 2 & $1 \cdot 3 \times 10^{-12}$ \\
10 & 4 & $1 \cdot 7 \times 10^{-12}$ \\
10 & 6 & $2 \cdot 1 \times 10^{-12}$ \\
15 & 2 & $1 \cdot 7 \times 10^{-12}$ \\
15 & 4 & $4 \cdot 2 \times 10^{-12}$ \\
15 & 6 & $2 \cdot 0 \times 10^{-12}$ \\
20 & 2 & $1 \cdot 5 \times 10^{-12}$ \\
20 & 4 & $1 \cdot 5 \times 10^{-12}$ \\
20 & 6 & $1 \cdot 2 \times 10^{-12}$
\end{tabular}




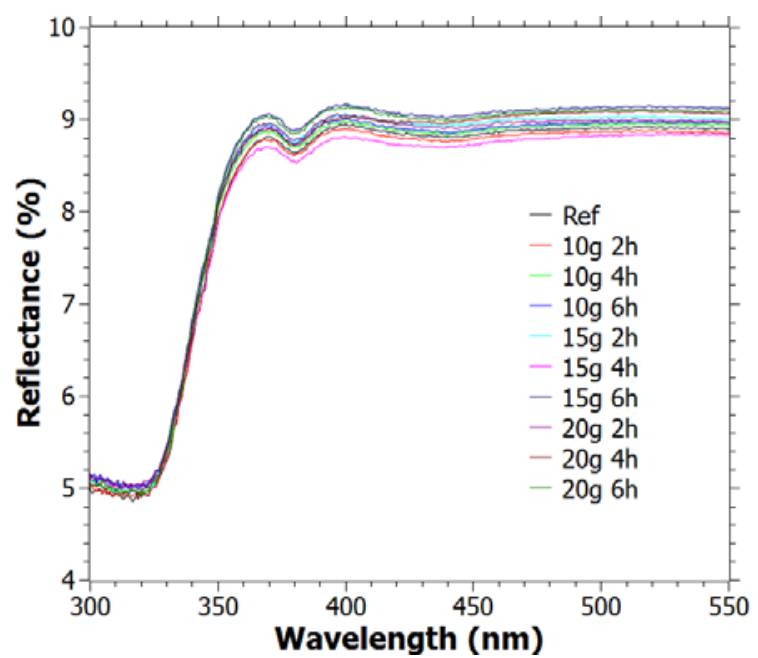

Figure 9. Reflectance spectra $R \%$ for wavelengths of 300-550 nm [Colour available online]

\subsection{UV-VIS-NIR reflectance and refractive index}

The $\mathrm{K}^{+}$ions are incorporated in the glass surface as $\mathrm{K}_{2} \mathrm{O}$, which leads to an increase of the refractive index $\mathrm{n}_{\mathrm{s}}$ due to three physical mechanisms; ionic size, ionic polarisability and induced compressive stresses. ${ }^{(30)}$ As a consequence to the refractive index increase $\left(\Delta n_{\mathrm{s}}\right)$, more light will be reflected. The ionic size of $\mathrm{K}^{+}(1 \cdot 33$ $\AA)$ and the ionic polarisability $\left(1.33 \AA^{3}\right)$ compared to $\mathrm{Na}^{+}(0.95 \AA)$ and $\left(0.43 \AA^{3}\right)$, respectively, give a value of $\Delta n_{\mathrm{s}}$ of $3 \times 10^{-4}$. $^{(31)}$ It is approximately two orders of magnitude lower than reported $\Delta n_{\mathrm{s}}$ values achieved via $\mathrm{K}^{+}-\mathrm{Na}^{+}$ion exchange, ${ }^{(32)}$ which means that induced compressive stresses is the major factor of refractive index increase. In the current study, $n_{\mathrm{s}}$ was calculated from the reflectance spectra at the specific wavelength of $520 \mathrm{~nm}$, according to Equation (2). The reflectance spectra $R \%$ in the range $300 \leq \lambda \leq 550 \mathrm{~nm}$ are shown in Figure 9. The calculated values of $n_{\mathrm{s}}$ as well as the relative changes of $n_{\mathrm{s}}$ after the ion exchange are summarised in Table 4 . In a review paper by Ramasvamy $^{(32)}$ changes in the refractive index of $\Delta n_{\mathrm{s}} \leq 0 \cdot 01$ were reported after $\mathrm{K}^{+}-\mathrm{Na}^{+}$ion exchange, which is in good agreement with the results shown in Table 4 . It shall be noted that the calculated $n_{\mathrm{s}}$ from $\mathrm{R} \%$ cannot be compared with each other. It is likely that the

Table 4. Calculated refractive index $n_{s}$ from reflectance spectra $R \%$ at $520 \mathrm{~nm}$

\begin{tabular}{lllr} 
Concentration & Treatment time $(h)$ & \multicolumn{2}{c}{ Calculated from $R \%$} \\
& & $n_{s}$ & $\Delta n_{s}$ \\
\hline Ref & Ref & 1.5235 & \\
10 & 2 & 1.5218 & -0.002 \\
10 & 4 & 1.5252 & 0.002 \\
10 & 6 & 1.5257 & 0.002 \\
15 & 2 & 1.5286 & 0.005 \\
15 & 4 & 1.5196 & -0.004 \\
15 & 6 & 1.5336 & 0.010 \\
20 & 2 & 1.5269 & 0.003 \\
20 & 4 & 1.5312 & 0.008 \\
20 & 6 & 1.5320 & 0.009
\end{tabular}

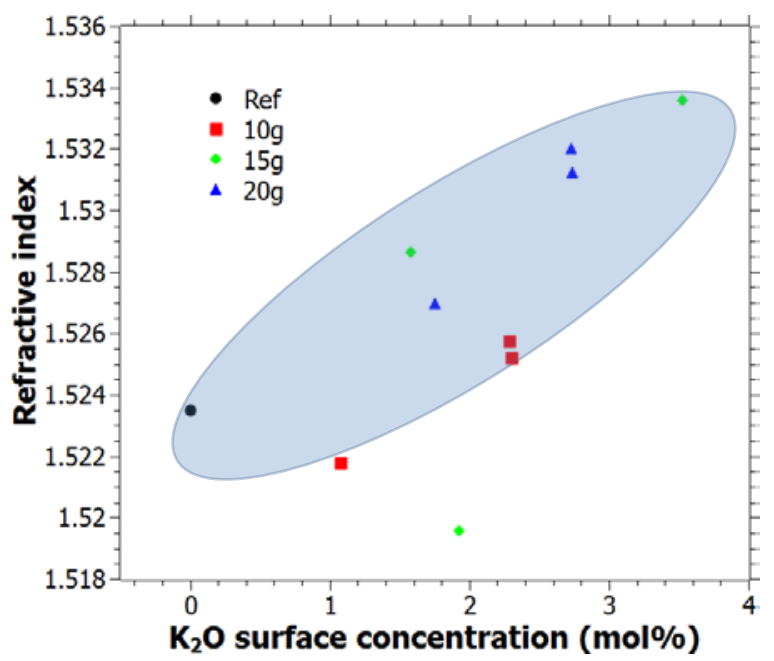

Figure 10. Refractive index, $n_{s}$, determined from $R \%$, as a function of the $\mathrm{K}_{2} \mathrm{O}$ surface concentration (at $0.5 \mu \mathrm{m}$ ) [Colour available online]

generated compressive stresses affect the $n_{\mathrm{s}}$ values.

The refractive index for the ion exchanged samples was assumed to increase with increasing salt concentration and treatment time, respectively. Apart from the glass specimen treated for $4 \mathrm{~h}$ with $15 \mathrm{~g} \mathrm{KCl}$ per $100 \mathrm{ml} \mathrm{H}_{2} \mathrm{O}, n_{\mathrm{s}}$ increases with increasing treatment time. On the contrary, such a relationship cannot be verified for $n_{\mathrm{s}}$ as a function of the salt concentration. It should also be noted that another sample, treated for $2 \mathrm{~h}$ with a salt concentration of $10 \mathrm{~g} \mathrm{KCl}$ per $100 \mathrm{ml}$ $\mathrm{H}_{2} \mathrm{O}$, exhibits a lower $n_{\mathrm{s}}$ than the as-received sample, see Table 4 . This can probably be attributed to small surface scratches or a contamination of the surface, which significantly influence the reflectance measurements. In Figure 10 the refractive index as a function of $\mathrm{K}_{2} \mathrm{O}$ surface concentration is shown. Except for the $10 \mathrm{~g}$ series and the specimen treated with $15 \mathrm{~g}$ for $4 \mathrm{~h}$, there is a roughly linear trend. This indicates that the surface concentration of the studied method is closely

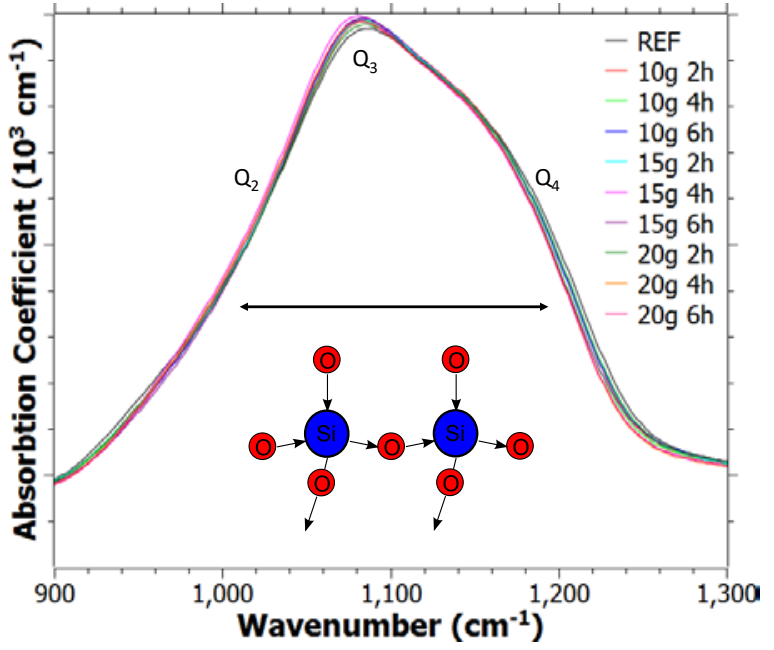

Figure 11(a). IR-RS spectra for wavenumbers between 900 and $1300 \mathrm{~cm}^{-1}$, demonstrating the narrowing and the shift of the peak at $1090 \mathrm{~cm}^{-1}$ [Colour available online] 
Table 5. Peak breadths of the peaks at 1090, 785 and $495 \mathrm{~cm}^{-1}$

\begin{tabular}{lllll}
$\left.\begin{array}{l}\text { Concentration } \\
(\mathrm{g} \mathrm{KCl} / 100 \mathrm{ml} \mathrm{H}\end{array} \mathrm{O}\right)$ & $\begin{array}{l}\text { Treatment } \\
\text { time }(\mathrm{h})\end{array}$ & $\begin{array}{l}\text { Peak broadness } \\
\text { at } ~ 1090 \mathrm{~cm}^{-1}\end{array}$ & $\begin{array}{l}\text { Peak broadness } \\
\text { at } \sim 785 \mathrm{~cm}^{-1}\end{array}$ & $\begin{array}{l}\text { Peak broadness } \\
\text { at } \sim 495 \mathrm{~cm}^{-1}\end{array}$ \\
\hline Ref & Ref & 186 & 65 & 69 \\
10 & $2 \mathrm{~h}$ & 182 & 57 & 66 \\
10 & $4 \mathrm{~h}$ & 181 & 57 & 64 \\
10 & $6 \mathrm{~h}$ & 181 & 56 & 64 \\
15 & $2 \mathrm{~h}$ & 183 & 59 & 66 \\
15 & $4 \mathrm{~h}$ & 182 & 58 & 66 \\
15 & $6 \mathrm{~h}$ & 179 & 58 & 65 \\
20 & $2 \mathrm{~h}$ & 182 & 64 & 68 \\
20 & $4 \mathrm{~h}$ & 181 & 63 & 67 \\
20 & $6 \mathrm{~h}$ & 181 & 58 & 67
\end{tabular}

connected with the induced compressive stresses in the glass surface.

\subsection{Infrared reflectance spectroscopy (IR-RS)}

Penetration of $\mathrm{K}^{+}$by ion exchange does not create new absorption bands in the IR-RS spectra but affects the peak of the Si-O stretching vibration $\left(\sim 1090 \mathrm{~cm}^{-1}\right)$ by narrowing the peak. ${ }^{(33)}$ As can be seen in Figure 11(a) and Table 5, the treated samples exhibit a small peak narrowing which can be linearly correlated to the surface concentration of $\mathrm{K}_{2} \mathrm{O}$, see Figure $11(\mathrm{~b})$. Furthermore, the peak $1090 \mathrm{~cm}^{-1}$ is shifted towards lower wavenumbers and a small increase in the absorption coefficient can be noticed. A peak narrowing in ion exchanged glasses has previously been shown in soda-lime-silica flat glass by Ingram et $\mathrm{al}^{(34,35)}$ and in aluminoborosilicate glass by Stavrou et $a l^{(33)}$ This feature corresponds to the chemical equilibrium $\mathrm{Q}^{2}+\mathrm{Q}^{4} \rightleftharpoons 2 \mathrm{Q}^{3}$. For $\mathrm{K}^{+}$ion exchange this chemical equilibrium is shifted to the right side, i.e. towards more $\mathrm{Q}^{3}$ units, while for $\mathrm{Ag}^{+}$ion exchange, the equilibrium shifts to the left side, i.e. a peak broadening occurs. Leboeuf et $a l^{(36)}$ studied $\mathrm{K}^{+}$ion exchange in sodalime-silica flat glass and also reported an increase in $\mathrm{Q}^{3}$ units. However, a decrease in the absorption coefficient with increasing treatment time had also

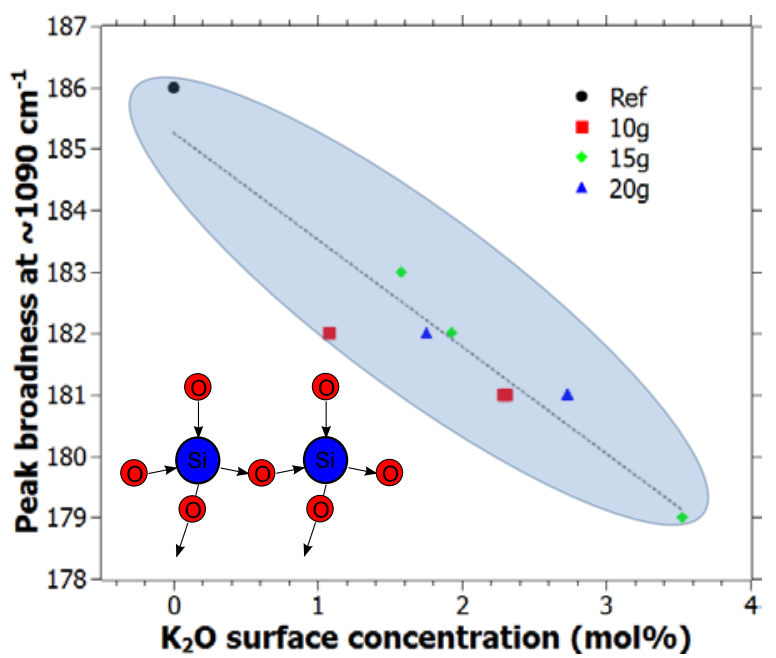

Figure 11(b). Peak broadness of $1090 \mathrm{~cm}^{-1}$ peak as a function of $\mathrm{K}_{2} \mathrm{O}$ surface concentration (at $0.5 \mu \mathrm{m}$ ) [Colour available online] been shown, which cannot be seen in the present study. Doremus ${ }^{(37)}$ studied the hydration of alkali silicate glass surfaces by infrared spectroscopy. Two peaks were observed in non-hydrated glass, which correspond to the Si-O-Si stretching vibration, 1100 and $\sim 1050 \mathrm{~cm}^{-1}$, and another one assigned to the $\mathrm{Si}-\mathrm{O}-\mathrm{M}^{+}$stretching vibration at $\sim 950 \mathrm{~cm}^{-1}$, where $\mathrm{M}^{+}$ stands for an alkali ion. As the water reacts with the glass, hydronium ions exchanges with the alkali ions, the absorption band at $\sim 950 \mathrm{~cm}^{-1}$ starts to decrease, while the absorption bands at $\sim 1100 \mathrm{~cm}^{-1}$ and $\sim 1050$ $\mathrm{cm}^{-1}$ increase, due to the replacement of $\mathrm{Si}-\mathrm{O}-\mathrm{M}^{+}$by $\mathrm{Si}-\mathrm{O}-\mathrm{H}-\mathrm{O}-\mathrm{H}_{2}$. In the current experiments, the atmosphere contains water vapour and this might explain the increasing absorption coefficient at around 1090 $\mathrm{cm}^{-1}$ as well as the shift towards lower wavenumbers, see Figure 11(a). Another reason for the peak-shift to lower frequency, i.e. to lower resonance energy of vibration, can be a widening of the $\mathrm{Si}-\mathrm{O}-\mathrm{Si}$ angle, presumably due to the incorporation of the larger $\mathrm{K}^{+}$ ions, see Figure 11(c). Such an observation reflects the more complex mechanism of ion exchange beyond simple elastic stuffing. Similar observations have been made in recent computational simulation studies of this issue. ${ }^{(38)}$

In addition, the ion exchange induces several other changes in the IR-RS spectra.

- A narrowing of the O-Si-O rocking peak at 495

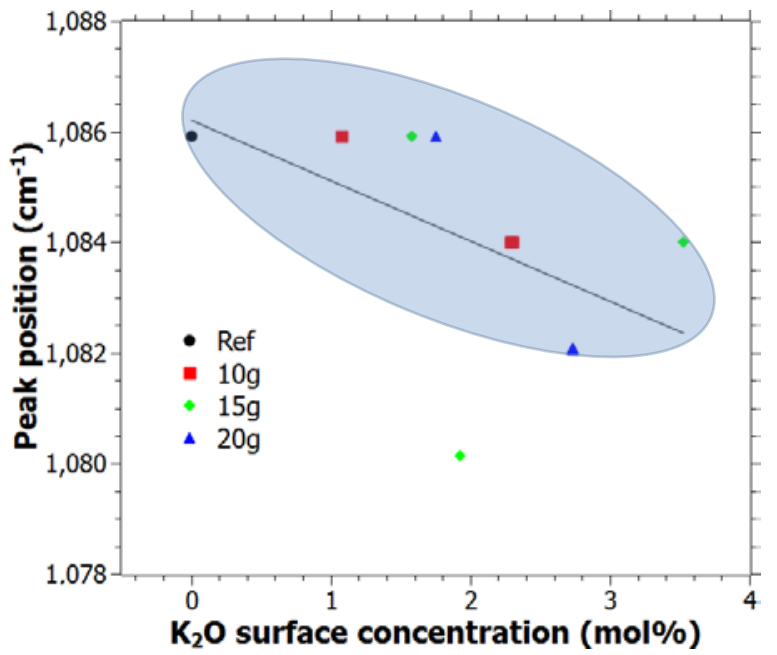

Figure 11(c). Peak position of $1090 \mathrm{~cm}^{-1}$ peak as a function of $\mathrm{K}_{2} \mathrm{O}$ surface concentration (at $0.5 \mu \mathrm{m}$ ) [Colour available online] 


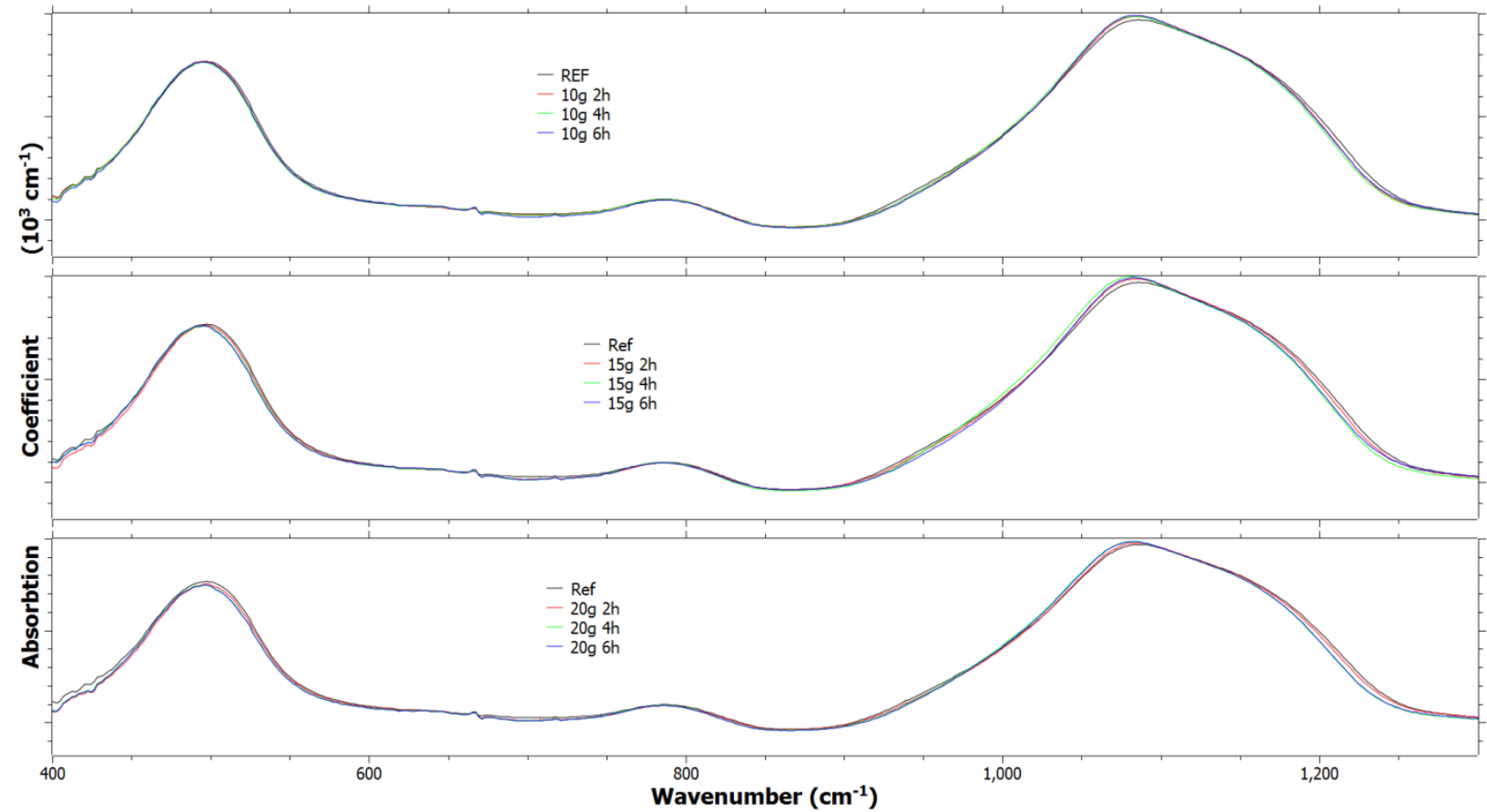

Figure 12. Overview of the infrared reflectance spectra spectra between 400 and $1300 \mathrm{~cm}^{-1}$ [Colour available online]

$\mathrm{cm}^{-1}$, see Table 5 and Figure 12. This area can be attributed to the flexion vibration modes zone of $\mathrm{SiO}_{4}$ tetrahedra. ${ }^{(36)} \mathrm{In}$ addition the absorption coefficient of this peak reduces, except for the sample treated for $2 \mathrm{~h}$ with $10 \mathrm{~g} \mathrm{KCl}$ per $100 \mathrm{ml}$ $\mathrm{H}_{2} \mathrm{O}$.

- A reduction of the absorption coefficient for the minima at $\sim 700 \mathrm{~cm}^{-1}$, see Figure 12 .

- A narrowing of the $\mathrm{Si}-\mathrm{O}$ symmetric stretching peak at $785 \mathrm{~cm}^{-1}$, see Table 5 and Figure 11, as well as a small shift towards lower wavelengths. The absorption coefficient of this peak also reduces, except for the samples treated for 2 and $4 \mathrm{~h}$ with $10 \mathrm{~g} \mathrm{KCl}$ per $100 \mathrm{ml} \mathrm{H}_{2} \mathrm{O}$. This is in accordance with the study of Lebeouf et al. ${ }^{(36)}$

- An increasing absorption coefficient for the peaks at $\sim 2320$ and $\sim 2353 \mathrm{~cm}^{-1}$. The peak at $2320 \mathrm{~cm}^{-1}$ also shows shifts to lower wavenumbers.

- A decrease in the absorption coefficient for the minimum at $2373 \mathrm{~cm}^{-1}$ as well as a shift to higher wavenumbers.

- A small increase in the absorption coefficient at $\sim 3791 \mathrm{~cm}^{-1}$. This area corresponds to the $\mathrm{OH}-$ stretching vibrations in adsorbed molecular water and hydrogen bonding. ${ }^{(37,39)}$ Several other changes in this area indicate that reactions between the glass surface and the water vapour takes place during the thermal treatment.

\subsection{Nanoindentation and scratch/wear resistance}

The deposition of the $\mathrm{KCl}$ salt on the glass and the ion exchange process results in a modified surface enriched with $\mathrm{K}_{2} \mathrm{O}$. Presumably this surface modification should also change the surface mechanical properties. Therefore nanoindentation measurements were performed to give some information about the hardness $H$ and elastic modulus $E$, see Table 6 . On each sample ten indents were made to get a statistically valid average value. Given from the results in Table 6 both the indentation hardness and the elastic modulus of the modified glass surfaces are increased due to the treatment. The standard deviations of the

Table 6. Hardness $H$ and elastic modulus E determined by nanoindentation

\begin{tabular}{|c|c|c|c|c|c|c|c|}
\hline \multirow{2}{*}{$\begin{array}{l}\text { Concentration } \\
\left(\mathrm{g} \mathrm{KCl} / 100 \mathrm{ml} \mathrm{H} \mathrm{H}_{2} \mathrm{O}\right)\end{array}$} & \multirow{2}{*}{$\begin{array}{l}\text { Treatment time } \\
\text { (h) }\end{array}$} & \multicolumn{2}{|c|}{ Hardness (GPa) } & \multicolumn{2}{|c|}{ Elastic modulus (GPa) } & \multicolumn{2}{|c|}{ Temperature $\left({ }^{\circ} \mathrm{C}\right)$} \\
\hline & & Avr. & StDev. & Avr. & StDev. & Avr. & StDev. \\
\hline Ref & Ref & $6 \cdot 84$ & 0.03 & $77 \cdot 3$ & $0 \cdot 3$ & $30 \cdot 8$ & $<0 \cdot 1$ \\
\hline 10 & 2 & $7 \cdot 07$ & $0 \cdot 04$ & $77 \cdot 4$ & $0 \cdot 2$ & $30 \cdot 7$ & $<0 \cdot 1$ \\
\hline 10 & 4 & 6.95 & $0 \cdot 05$ & $77 \cdot 5$ & $0 \cdot 2$ & $30 \cdot 8$ & $<0 \cdot 1$ \\
\hline 10 & 6 & $7 \cdot 41$ & 0.04 & $78 \cdot 7$ & $0 \cdot 4$ & $31 \cdot 2$ & $<0 \cdot 1$ \\
\hline 15 & 2 & $7 \cdot 03$ & $0 \cdot 04$ & $77 \cdot 8$ & $0 \cdot 2$ & $31 \cdot 1$ & $<0 \cdot 1$ \\
\hline 15 & 4 & $7 \cdot 39$ & 0.03 & $78 \cdot 9$ & $0 \cdot 2$ & $31 \cdot 1$ & $<0 \cdot 1$ \\
\hline 15 & 6 & $7 \cdot 41$ & $0 \cdot 04$ & $79 \cdot 1$ & $0 \cdot 3$ & $31 \cdot 2$ & $<0 \cdot 1$ \\
\hline 20 & 2 & $7 \cdot 07$ & $0 \cdot 03$ & $77 \cdot 6$ & $0 \cdot 2$ & $31 \cdot 3$ & $<0 \cdot 1$ \\
\hline 20 & 4 & $7 \cdot 31$ & $0 \cdot 04$ & $78 \cdot 2$ & $0 \cdot 3$ & $31 \cdot 6$ & $<0 \cdot 1$ \\
\hline 20 & 6 & $7 \cdot 40$ & 0.04 & 78.9 & $0 \cdot 3$ & $31 \cdot 4$ & $<0 \cdot 1$ \\
\hline
\end{tabular}


(a)

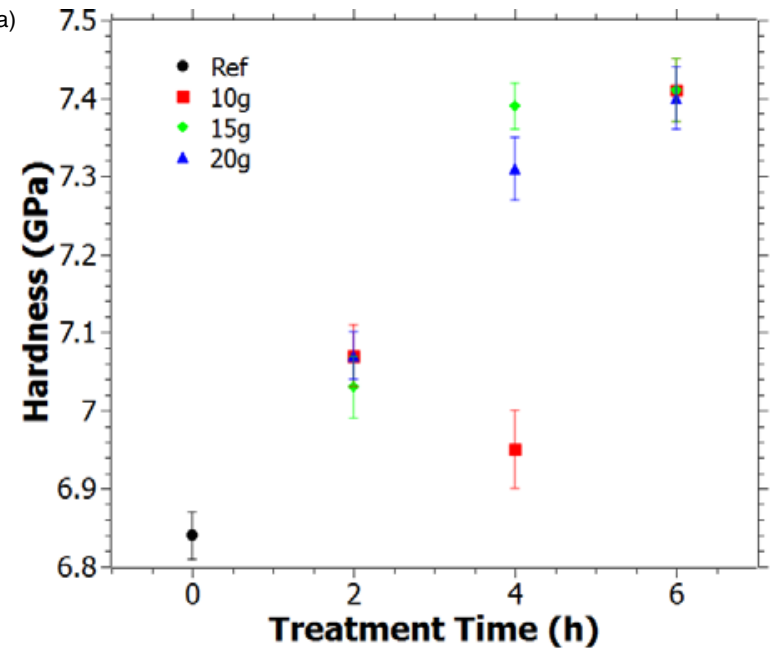

(b)

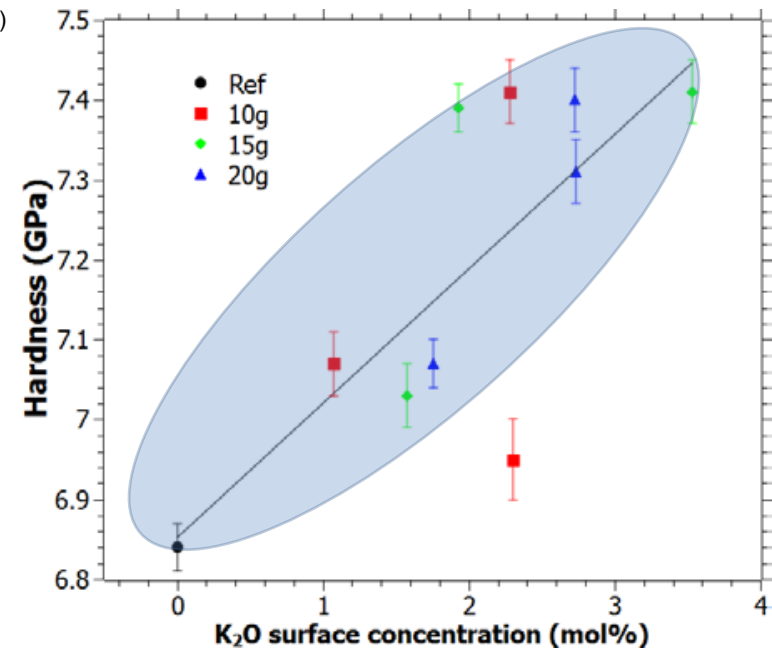

Figure 13. (a) Hardness $\mathrm{H}$ of $\mathrm{K}^{+}$ion exchanged flat glass as a function of treatment time. (b). Hardness $\mathrm{H}$ of $\mathrm{K}^{+}$ion exchanged flat glass as a function of $\mathrm{K}_{2} \mathrm{O}$ surface concentration [Colour available online]

samples are approximately on the same level for all samples, indicating that a relatively homogeneous ion exchange treatment has taken place.

In Figure 13(a) the values of $H$ are shown as a function of the treatment time. In the series treated with 15 and $20 \mathrm{~g} \mathrm{KCl}$ per $100 \mathrm{ml} \mathrm{H}_{2} \mathrm{O}$ a relatively linear increase of $H$ with increasing treatment time can be seen. On the other hand, this trend cannot be verified for the series treated with $10 \mathrm{~g} \mathrm{KCl}$ per 100 $\mathrm{ml} \mathrm{H}_{2} \mathrm{O}$, due to the discrepancy in the sample treated for $4 \mathrm{~h}$. However, the remaining glass samples in the series treated with $10 \mathrm{~g} \mathrm{KCl}$ per $100 \mathrm{ml} \mathrm{H}_{2} \mathrm{O}$ coincide quite well with the trends of the other series. As can be deduced from Figure 13(a), the concentration of the salt mixture itself does not affect the values of $H$ much. The treatment time seem to be dominant for the improvement of $H$ and also the $\mathrm{K}_{2} \mathrm{O}$ surface concentration follows a quite linear trend with the hardness, see Figure 13(b). In Figure 14 the values of $E$ are shown as a function of the treatment time. Similar to $H$ an increase of $E$ with increasing treatment time was found, with a deviation in the sample treated for $4 \mathrm{~h}$ with $10 \mathrm{~g} \mathrm{KCl}$ per $100 \mathrm{ml} \mathrm{H}_{2} \mathrm{O}$. In addition, the concentration of $\mathrm{KCl}$ seems to have a lesser influence on $E$ than the treatment time. However, some small changes with concentration, with the order 15 $\mathrm{g}>20 \mathrm{~g}>10 \mathrm{~g} \mathrm{KCl}$ per $100 \mathrm{ml} \mathrm{H}_{2} \mathrm{O}$ is visible, see Figure 13(a). The same order cannot be seen for the values of $H$, except for the series treated for $4 \mathrm{~h}$. In several studies on the hydration of soda-lime-silica glasses ${ }^{(40-42)}$ notable changes in $H$ and $E$ were observed with the progressive hydration of the glass surface. Kolluru et $a l^{(42)}$ suggested that the reduction of the nanomechanical properties may also depend on the exposure history of the glasses. However, in contrast to our study, the indentation studies of the nanomechanical properties of the hydrated soda-lime-silica glass were at considerably lower depths $(<200 \mathrm{~nm}) .^{(40-42)}$ Fett $e t a l^{(43)}$ studied stresses in hydronium ion ex- changed soda-lime-silica glasses and noticed the formation of high compressive stresses after the ion exchange. Furthermore, they found that the depth of layer, DoL, depends significantly on the temperature but also on the square root of the treatment time. Sil'vestrovich et al ${ }^{(24)}$ also reported data on the hardness, an increase from 5.20 to 6.25 GPa was found for the aerosol method, while the salt bath gave a value of $7 \cdot 1 \mathrm{GPa}$. The increase in the present study is considerably lower than what was reported by Sil'vestrovich et al, however, there are also differences in the experimental procedure, which could explain this discrepancy.

The scratch/wear resistance was investigated with a nanoindenter, equipped with a conical tip with a nominal tip radius of $5 \mu \mathrm{m}$. The wear displacement was measured after every 10th cycle of wear. In Figure 15(a) the results are shown for the samples treated with $15 \mathrm{~g} \mathrm{KCl}$ per $100 \mathrm{ml} \mathrm{H}_{2} \mathrm{O}$ as a function of treatment time. A strong deviation in the wear displacement can already be seen after 20 wear

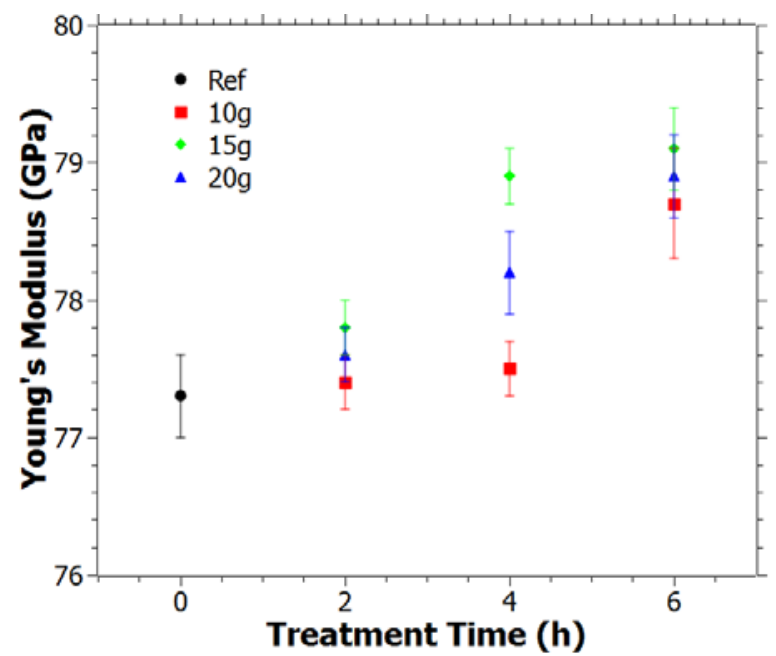

Figure 14. Elastic modulus $E$ of $\mathrm{K}^{+}$ion exchanged flat glass as a function of treatment time [Colour available online] 
(a)

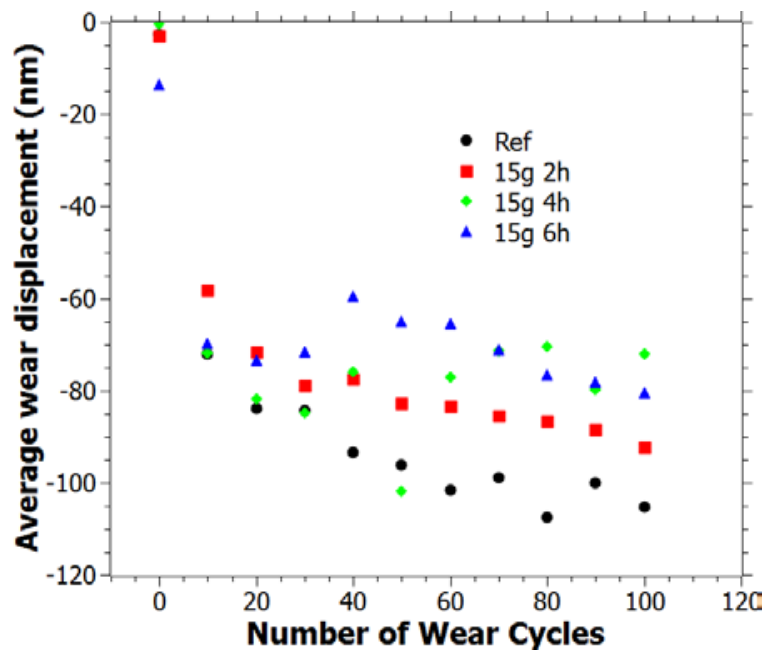

(b)

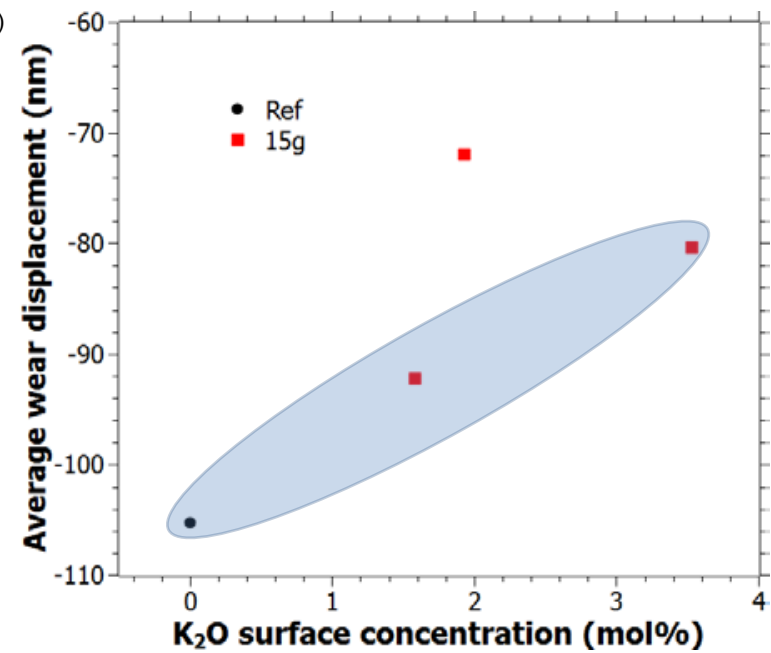

Figure 15. (a) Average wear displacement as a function of the number of wear cycles. (b) Average wear displacement as a function of surface concentration of $\mathrm{K}_{2} \mathrm{O}$ [Colour available online]

cycles, with the reference sample exhibit the largest average wear displacement into the glass surface, while the others followed in the order $2<4 \sim 6 \mathrm{~h}$. The scratch/wear resistance can be linearly correlated to the surface concentration of $\mathrm{K}_{2} \mathrm{O}$, except for the specimen treated with $15 \mathrm{~g} \mathrm{KCl}$ per $100 \mathrm{ml} \mathrm{H}_{2} \mathrm{O}$ for 4 $\mathrm{h}$, see Figure 15(b). In general, the modified glasses show improved scratch/wear resistance, see Figure 15(a) and (b).

\section{Conclusions and further work}

The method of chemical strengthening of flat glass by vapour deposition of $\mathrm{KCl}$ salt and in-line $\mathrm{K}^{+}$ ion exchange has been demonstrated. The surface modification has been shown to induce structural changes as well as increase the refractive index, hardness and scratch/wear resistance. This method has the potential to be used in a production line of flat glass, e.g. float line, down/up-drawn flat glass or fusion process. The process can also be used for the chemical strengthening of other glass compositions as well, e.g. aluminosilicate glasses, which are generally more effectively strengthened. Furthermore, the process of salt deposition on flat glass and in-line ion exchange is difficult to predict, since it is a complex and challenging process. There are many parameters to control, e.g. temperature, salt concentration, treatment time, pressure in aerosol generator, salt distribution on glass as well as salt adhesion on the glass surface.

Further work is advised to involve another glass composition, e.g. aluminosilicate glass, and bending strength tests to quantify the actual strengthening effect of the treatment. Furthermore, it is advised to use two furnaces, one furnace for aerosol generation and another furnace for salt deposition so that a constant temperature over the whole samples is created. Also the pressure in the aerosol generator can be modified in order to create a more homogeneous deposited salt layer and other potential precursors as well as solvents should be investigated. Potentially the method can find applications where the depth of the surface modification is not as important or for glass products which must have low production costs.

\section{Acknowledgement}

We wish to acknowledge ÅForsk for providing funding for this project (Grant No. 13-364). The MarieCurie Fellowship granted to Dr Stefan Karlsson via the VINNMER programme (Vinnova) co-funded by Marie Curie Actions FP7-PEOPLE-2011-COFUND (GROWTH 291795) is gratefully acknowledged. We also wish to acknowledge Pilkington Sverige $\mathrm{AB}$ for providing float glass for the experiments in the project. Furthermore, we wish to acknowledge Maria Lang (Glafo - the Glass Research Institute) for performing SEM/EDS measurements.

\section{References}

1. Wondraczek, L., Mauro, J. C., Eckert, J., Kühn, U., Horbach, J., Deubener, J. \& Rouxel, T. Towards ultrastrong glasses. Adv. Mater., 2011, 23 (39), 4578-86.

2. Kurkjian, C. R., Gupta, P. K. \& Brow, R. K. The strength of silicate glasses: what do we know, what do we need to know? Int. J. Appl. Glass Sci., 2010, 1 (1), 27-37.

3. Mauro, J. C., Philip, C. S., Vaughn, D. J. \& Pambianchi, M. S. Glass science in the United States: current status and future directions. Int. J. Appl. Glass Sci., 2014, 5 (1), 2-15.

4. Mould, R. E. The Strength of Inorganic Glasses, in Fracture of Metals, Polymers and Glasses. Edited by L. J. Bonis, J. J. Duga \& J. J. Gilman, Plenum Press, New York, 1967, 119-49.

5. Karlsson, S., Jonson, B. \& Stålhandske, C. The technology of chemical glass strengthening - a review. Glass Technol.: Eur. J. Glass Sci. Technol. A, 2010, 51 (2), 41-54.

6. Kistler, S.S., Stresses in glass produced by nonuniform exchange of monovalent ions. J. Am. Ceram. Soc., 1962, 45 (2), 59-68.

7. Acloque, P. \& Tochon, J. Measurement of the mechanical strength of glass after reinforcement. In Compte Rendu Symposium sur la Résistance Mécanique du Verre et les Moyens de l'Améliorer. 1961. Florence, Italy, 25-29 Sept. 1961, Union Scientifique Continentale du Verre, Charlroi, Belgium 1962, 1044. 


\section{S. KARLSSON ET AL: ALKALI SALT VAPOUR DEPOSITION AND IN-LINE ION EXCHANGE ON FLAT GLASS}

8. Varshneya, A. K. The physics of chemical strengthening of glass: room for a new view. J. Non-Cryst. Solids, 2010, 356 (44-49), 2289-94.

9. Varshneya, A. K. Chemical strengthening of glass: lessons learned and yet to be learned. Int. J. Appl. Glass Sci., 2010, 1 (2), 131-42.

10. Gy, R. Ion exchange for glass strengthening. Mater. Sci. Eng. B, 2008, 149 (2), 159.

11. Varshneya, A. K. \& Kreski, P. K. The chemistry of chemical strengthening of glass. In Processing, Properties, and Applications of Glass and Optical Materials, John Wiley \& Sons, Inc., 2012, 107-14.

12. Corning' Gorilla Glass brings King Kong glass strength to high-tech toys. Am. Ceram. Soc. Bull., 2010, 89 (8), 41-2.

13. Geithe, A. Touching allowed. Schott Technol. Mag.: Solutions, 2011, $28-29$.

14. AGC Unveils Damage-Resistant Dragontrail ${ }^{\mathrm{TM}}$ Glass for Smartphone, Tablet PC, TV Makers worldwide. Press release, 2011.

15. Nippon Electric Glass has started mass-producing specialty glass for chemical strengthening, which is used for cover glass of smart phones and mobile devices. Press release.

16. Lee, M. Y. M. Gases for glass production, special treatment and coatings. Gases Instrum. Int. Mag., 2012.

17. Patschger, M., Bocker, C. \& Rüssel, C. High-Strength Frosted Glass by Ion Exchange of Float Glass with a Potassium Water Glass Film. Int. J. Appl. Glass Sci., 2015. doi: 10.1111/ijag.12174.

18. Karlsson, S. Modification of Float Glass Surfaces by Ion Exchange. Doctoral Thesis, Linnaeus University: Växjö, 2012.

19. Karlsson, S., Jonson, B. \& Wondraczek, L. Copper, silver, rubidium and caesium ion exchange in soda-lime-silicate float glass by direct deposition and in line melting of salt pastes. Glass Technol.: Eur. J. Glass Sci. Technol. A, 2012, 53 (1), 1-7.

20. Poole, J. P. \& Snyder, H. C. Chemically strengthened glass containers by ion exchange. Glass Technol., 1975, 16 (5), 109-13.

21. Schelinski, S., Patzig, D., Heinrich, K. \& Grueger, B. GDR Patent No. 157966, VEB Wissenschaftlich-Technischer Betrieb Wirtschaftsglas Bad Muskau, 1982.

22. Schelinski, S., Patzig, D., Heinrich, K. \& Grueger, B. US Patent 4,397,668, VEB Wissenschaftlich-Technischer Betrieb Wirtschaftsglas Bad Muskau, 1983.

23. Schnieder, A. Emerging on the market-processes for continuous chemical tempering of glass (id:4259654), in VDMA (23.06.2014), 2014

24. Sil'vestrovich, S. I., Samkova, L. G., Sobolev, E. V., Gorbachev, V. V., Byshrikov, A. S. \& Grigorova, E. K. Ion-exchange modification of glass surface by means of an aerosol method. Sov. J. Glass Phys. Chem., 1986, $12(2), 180-7$

25. Sil'vestrovich, S. I., Samkova, L. G., Kazakov, V. D. \& Korshunova, L. F. Strengthening industrial glasses by ion exchange with solid-phase reagents. Glass Ceram., 1984, 41 (11), 471-4.

26. International Commission on Glass, TC-2, The chemical analysis of colourless soda-lime-magnesia-silica glasses. Glass Technol., 1980, 21, Part 1: 67-71, Part 2: 71-5, Part 3: 209-12, Part 4: 212-14, Part 5: 273-4,
Part 6: 274-8

27. Karlsson, S., Jonson, B., Sundberg, P. \& Stålhandske, C. Surface analysis of float glass using Surface Ablation Cell (SAC) Part 2: Determination of the diffusion characteristics of $\mathrm{K}^{+}-\mathrm{Na}^{+}$ion exchange. Glass Technol.: Eur. J. Glass Sci. Technol. A, 2010, 51 (2), 55-62.

28. Limbach, R., Rodrigues, B. P. \& Wondraczek, L. Strain-rate sensitivity of glasses. J. Non-Cryst. Solids, 2014, 404, 124-34.

29. Schaeffer, H. A. Transport phenomena and diffusion anomalies in glass. Mater. Ceram., 2012, 64 (2), 156-61.

30. Tervonen, A., West, B. R. \& Honkanen, S. Ion-exchanged glass waveguide technology: a review. Opt. Eng., 2011, 50 (7), 071107.

31. Albert, J. \& Yip, G. L. Stress-induced index change for $\mathrm{K}^{+}-\mathrm{Na}^{+}$ion exchange in glass. Electron. Lett., 1987, 23 (14), 737-8.

32. Ramaswamy, R. V. \& Srivastava, R. Ion-exchanged glass waveguides: a review. J. Lightwave Technol., 1988, 6 (6), 984.

33. Stavrou, E., Palles, D., Kamitsos, E. I., Lipovskii, A., Tagansev, D., Svirko, Y. \& Honkanen, S. Vibrational study of thermally ionexchanged sodium aluminoborosilicate glasses. J. Non-Cryst. Solids, 2014, 401, 232-6

34. Ingram, M. D., Wu, M.-H., Coats, A., Kamitsos, E. I., Varsamis, C. P. E., Garcia, N. \& Sola, M. Evidence from infrared spectroscopy of structural relaxation during field assisted and chemically driven ion exchange in soda-lime-silica glasses. Phys. Chem. Glasses: Eur. J. Glass Sci. Technol. B, 2005, 46 (2), 84-9.

35. Ingram, M. D., Davidson, J. E., Coats, A. M., Kamitsos, E. I. \& Kapoutsis, J. A. Origins of anomalous mixed-alkali effects in ion-exchanged glasses. Glastech. Ber.: Glass Sci. Technol., 2000, 73 (4), 89.

36. Leboeuf, V., Blondeau, J.-P., De Sousa Meneses, D. \& Véron, O. Potassium ionic exchange in glasses for mechanical property improvement. J. Non-Cryst. Solids, 2013, 377, 60-5.

37. Doremus, R. H. Infrared spectroscopy of surfaces of glasses containing alkali ions. J. Non-Cryst. Solids, 1980, 41 (1), 145-9.

38. Tandia, A., Vargheese, K. D. \& Mauro, J. C. Elasticity of ion stuffing in chemically strengthened glass. J. Non-Cryst. Solids, 2012, 358 (12-13), 1569-74.

39. Husung, R. D. \& Doremus, R. H. The infrared transmission spectra of four silicate glasses before and after exposure to water. J. Mater. Res., 1990, 5 (10), 2209-17.

40. Tadjiev, D. R. \& Hand, R. J. Surface hydration and nanoindentation of silicate glasses. J. Non-Cryst. Solids, 2010, 356 (2), 102-8.

41. Gonzalez Rodriguez, J. A. \& Hand, R. J. Evolution of the modulus and hardness of the tin and air sides of float glass as a function of hydration time. Glass Technol.: Eur. J. Glass Sci. Technol. A, 2013, 54 (1), 36-41.

42. Kolluru, P. V., Green, D. J., Pantano, C. G. \& Muhlstein, C. L. Effects of surface chemistry on the nanomechanical properties of commercial float glass. J. Am. Ceram. Soc., 2010, 93 (3), 838-47.

43. Fett, T., Guin, J. P. \& Wiederhorn, S. M. Stresses in ion-exchange layers of soda-lime-silicate glass. Fatigue Fract. Eng. Mater. Struct., 2005, 28 (6), 507-14. 